\title{
Keshya drugs in Bhava Prakasha Nighantu: A Review
}

\section{Review Article}

\section{Dhiraj Kumar Vishwakarma $^{1 *}$, Sonal Bhola ${ }^{1}$}

\author{
1. Post graduate Scholar, Department of Dravyaguna, S V Ayurvedic college and Hospital, Tirupati (A.P.)
}

\begin{abstract}
Beauty has very important role in our life. Hair plays very vital role in our beauty. A human body without hair would be seen just as a tree without leaves. So everyone has an ambition that his/her hair should be long, black and thick. As the hair is a beauty for women as well as men also, hair plays a significant role in personality. From the ancient time, hair has got exceptional place in our poetry especially for describing the beauty of women. In Ayurve$d a$ hairs are known as Kesha and the drugs which are suitable to hairs, are known as Keshya drugs. In this article we have made an effort to compile all the Keshya drugs which are described in Bhava Prakasha Nighantu.
\end{abstract}

Key points: Kesha, Keshya, Bhava Prakasha Nighantu.

\section{Introduction}

Lord Brahma has created all the creatures of this universe including human being, while creating the creatures. Brahma has done artistic job by giving aesthetic touch to the beings of this universe, similarly, as the painter paints the painting by giving different colours to it, so that his painting could look beautiful and attractive. In the same way, Brahma added 'Hairs of the scalp' an additive factor of personality. Beautiful, long and attractive hairs of the scalp add plus factor to the personality.

Hairs are present on most of the skin surfaces except the palms, palmer surfaces of fingers, the soles, and the planter surfaces of the feet. In adults, hair usually is most heavily distributed across the scalp, in the eyebrows, in the axilla, and around the external genitalia. Genetic and hormonal influences largely determine the thickness and the pattern of distribution of hairs. Although the protection it offers is limited, hair on the head guards the scalp from injury and the sun's rays. It also decreases heat loss from the scalp. Eye brows and eye lashes protect the eyes from foreign particles, as does hair in the nostrils and in the external ear canal.(1)

A normal human being has approximately 1 million hair follicles on his body, of which 1 lac hairs on the scalp. A hair normally grows at the rate of approximately $1 \mathrm{~cm}$ per month, but each hair grows in cycles, each cycle being constituted by -

- The growth phase (Anagen)

- The transition phase (Catagen)

- The resting phase (Telogen)

*Corresponding Author:

Dhiraj Kumar Vishwakarma

PG scholar, Department of Dravyaguna,

SV Ayurvedic College,

Tirupati-517507.

Mobile No.: 7569177387 ,

Email id: dhirajvishwa11@gmail.com
The catagen phase in a hair cycle usually lasts 3 weeks, while the telogen phase lasts 3 months. The duration of the anagen phase in different hair follicles however, varies depending upon the site of the body. In the scalp hair the duration of anagen phase can be as long as 10 years. After completing the anagen phase, each hair follicles enters into the catagen phase which is followed by telogen phase. The old hair however, falls off only after the completion of the telogen phase and when the new hair has already started growing in its place. (2)

In Ayurveda hairs are known as Kesha. The word 'Kesha' originally has been brought about from "shee" with "ach + aluk samasah" which has been explained as "ke mastake shete iti" by HalayudhaKosha (3)

\section{Keshotpatti}

There is no detailed description found in Ayurvedic claim regarding the producing of Kesha in particular. The Asthi Dhatu has emerged from Meda Dhatu. The Prasada portion and the Kitta portion are differentiated and the Kitta portion of it is Kesha or hair on the scalp. (Su.Su. 16/36, Ca. Chi. 15/19,A.H. Sa. 316/364). Sharangdhara, Shabdastoma Mahanidhi and Vedic index believe in the theory that Kesha are the Upadhatu of Majja Dhatu. (Sa. P. Kh.5/15, Sha. S.M. pg. 134)

\section{Kesha Sankhya}

In ancient many controversies have been noticed in the counting of the hair. The number of hair as per various texts may be summarized as under:

- According to Yagnyavalkya the total number of human hair is 3.5 crores.

- Acarya Caraka has described that there are 29956 Kesha, forms and shamashra in the body which are equal to the numbers of Dhamanigras (Ca.Sa. 7/14)

- According to Vidyotini Tika of Caraka Samhita the number of hair stated by Aptopadesha is 72 crores (Ca.Sa. 7/14)

- According to Susruta Samhita, there are mainly 4 
oblique Dhamanies, which supplies to Romakoopa and are responsible for the drainage of Sneha \& Sveda. Acccording to this statement one can believe that there are innumerable hairs of the body. ( $S u$. $S a$. 9/9).

\section{Kesha Poshana}

According to Acarya Caraka ingested food is digested to assimilable nutritional fluid (Ahara rasa) which further divides into two parts namely - essential fluid (Sara bhaga) and the excretory matter/waste matter (kitta). The waste matter is responsible for the production and nutrition of so many things like sweat, urine, hair, etc., and among them are the hair follicles the hair of the head and beard, hair of the body, etc., (Ca. Su. 28/5). According to Sushruta Kesha nutrition form the end part of Dhaman, which are attached to the Romakoops (Su.Sa.9/9)

\section{Kesha Varnotpatti}

Pertaining to the effect of prakiti, jati, vansha, desha, kala, etc., the colours of hair are also observed different just as black, brown, red golden, etc. While describing the beauty of hair, the colour of hair like that of the Bhramara has been mentioned. Regarding the production of the colour of hair, Ayurveda says that the production of each \& every element in this human body has been attributed to Panchamahabhoota. The production of hair colour has been attributed to Teja Mahabhoota as varnya in the Artha (Subject) of teja. One of the manifestation of teja is Bhrajaka pitta, which does all the colouring, particularly of skin work through out the body for the whole life. Teja when combines with Prithvi and Vata Mahabhoot then krisna varnya is produced. (Ca.Sa.8/15, Su. Sa.2/36)

\section{What are Keshya drugs?}

Keshya- The drugs which are beneficial for hair, make the hair healthy and black in color e.g. Bhringaraja. (4)

Keshya-Suitable to hair, Eclipta prostrata L., Black aloe wood L.(5)

Dravyas which are beneficial for Keshas are known as Keshya. These dravyas increases the length of Kesha and made its colour natural so it is divided into two parts-

- Kesha vardhana

- Kesha ranjana (6)

\section{Basic elements of hair}

In the origin and development of Kesha i.e. hair, there is significant need of Prithvi (earth element) and Akasha (space/ether) Mahabhoota. During the process of formation and development of hair, the successive role of other tissues can also be estimated; because, though its origin begins at the earliest for its appearance it takes much time. So the role of later dhatus like asthi and shukra can be well judged by this.

As far as the matter of hair and its growth is concerned, once again we can deduce the need of nutrition and essential body requirements as it is formed/derived from the later tissues. This is explained with the broad heading of Keshya concept. The word 'keshya' is suggestive of 'keshaaya hitam yat tat'. It means that which is good for hair. So the goodness of hair can be understood by three perspectives like-

1. Kesha sanjanana - that which helps in the origin of hair.

2. Kehsha vardhana-that which promotes hair growth or which makes hair dense and thick.

3. Kesha ranjana-that which gives dark black color to the hair. (7)

\section{Aims and Objectives}

The main aims and objective of this work is to evaluate all the Keshya drugs which are described in Bhava Prakasha Nighantu with their Rasa, Guna, Virya, Vipaka and Doshik karma, along with their latest researches already done in the reference of Keshya karma.

\section{Materials and Methods}

The drugs are taken from different vargas of Bhava Prakash Nighantu (Indian Materia Medica) of Shree Bhava Mishra (C.1500-1600 A.D.) commentary by Prof. Krishna Chandra Chunekar, published by Chaukhambha Bharati Academy, Varanasi, Reprint: year 2013. In this study we have selected only the drugs which are having Keshya karma described in sloka form.

The drugs identified are tabulated as in Table No 1.

\section{Researches already done on Keshya Karma of the above said Drugs: \\ Yashtimadhu:}

Petroleum ether extract of the root of Glycyrrhiza glabra is taken to investigate the hair growth in female Wister rats divided into 3 groups. After complete removal of hair from their dorsal skin, one group is treated with paraffin oil, (control), second group with $2 \%$ of minioxidil solution and third group with petroleum ether extract of G.glabra root, was applied for 30 days. During this period visual hair growth was observed and then skin biopsy was done for follicular density and cyclic phase. Animal treated with petroleum ether extract of root $G$. glabra showed significant hair growth as compared to other two groups. This study shows that petroleum ether extract root of G. glabra works as a hair growth agent for females.(8)

\section{Bhringaraj:}

The study was conducted to evaluate the methanol extract of Eclipta alba as a hair growth promoter. In this study the extract was applied topically to assess telogen to anagen transition in pigmented C57/ BL6 mice. The study showed that methanol extract of Eclipta alba may have hair growth promoting property. (9)

\section{Japa Pushpa:}

Study of polyherbal $\mathrm{HO} 4$ formulation of four drugs, Tridax procumbens (Linn.), Hibiscus rosasinensis (Linn.), Trigonella foenum graecum (Linn.), and Embilica officinalis (Linn.) for their 
Keshya drugs described in Bhava Prakasha Nighantu

$(V=$ Vata,$P=$ Pitta,$K=$ Kapha,$R=$ Rakta $)$

\begin{tabular}{|c|c|c|c|c|c|c|c|c|c|}
\hline $\begin{array}{l}\mathbf{S} . \\
\mathbf{N} \\
\mathbf{0}\end{array}$ & $\begin{array}{l}\text { Name of } \\
\text { Drugs } \\
\text { (part } \\
\text { used) }\end{array}$ & $\begin{array}{l}\text { Botanical } \\
\text { Name }\end{array}$ & Family & $\operatorname{Rasa}$ & Guna & Virya & $\overline{\text { Vipaka }}$ & $\begin{array}{l}\text { Doshagh } \\
\text { nata } \\
\text { ( karma) }\end{array}$ & $\begin{array}{l}\text { References } \\
\text { (Varga, } \\
\text { Sloka } \\
\text { no,Page no) }\end{array}$ \\
\hline 1 & $\begin{array}{l}\text { Vibhitaki } \\
\text { (Phala) }\end{array}$ & $\begin{array}{l}\text { Terminalia } \\
\text { bellirica } \\
\text { Roxb. }\end{array}$ & $\begin{array}{l}\text { Combreta- } \\
\text { ceae }\end{array}$ & Kasaya & Ruksha & Ushna & Madhura & $\begin{array}{l}\text { KP } \\
\text { shamaka } \\
\text { (Keshya) }\end{array}$ & $\begin{array}{l}\text { Haritkyadi, } \\
35,9\end{array}$ \\
\hline 2 & $\begin{array}{l}\text { Yasti- } \\
\text { madhu } \\
\text { (Moola) }\end{array}$ & $\begin{array}{l}\text { Glycyrrhiza } \\
\text { glabra Linn. }\end{array}$ & Fabaceae & Madhura & $\begin{array}{l}\text { Guru, } \\
\text { Susnigdha }\end{array}$ & Sheeta & Madhura & $\begin{array}{l}\text { PVR } \\
\text { shamaka } \\
\text { (Keshya) }\end{array}$ & $\begin{array}{l}\text { Haritkyadi, } \\
145,62\end{array}$ \\
\hline 3 & $\begin{array}{l}\text { Bakuchi } \\
\text { (Phala) }\end{array}$ & $\begin{array}{l}\text { Psoralea } \\
\text { corylifolia } \\
\text { Linn. }\end{array}$ & Fabaceae & $\begin{array}{l}\text { Madhura, } \\
\text { Tikta }\end{array}$ & Ruksha & Sheeta & Katu & $\begin{array}{l}K V \\
\text { shamak } \\
\text { (Keshya) }\end{array}$ & $\begin{array}{l}\text { Haritkyadi,2 } \\
06,119\end{array}$ \\
\hline 4 & $\begin{array}{l}\text { Bhallataka } \\
\text { (Vrint) }\end{array}$ & $\begin{array}{l}\text { Semicarpus } \\
\text { anacardium } \\
\text { Linn.f. }\end{array}$ & $\begin{array}{l}\text { Anacardi- } \\
\text { aceae }\end{array}$ & Madhura, & $\begin{array}{l}\text { Laghu, } \\
\text { Snigdha, } \\
\text { Tikshna }\end{array}$ & Ushna & Madhura & $\begin{array}{l}P \\
\text { shamaka } \\
\text { (Keshya) }\end{array}$ & $\begin{array}{l}\text { Haritkyadi,2 } \\
28,134\end{array}$ \\
\hline 5 & $\begin{array}{l}\text { Gambhari } \\
\text { (Phala) }\end{array}$ & $\begin{array}{l}\text { Gmelina } \\
\text { arborea } \\
\text { Linn. }\end{array}$ & $\begin{array}{l}\text { Verbenace- } \\
\text { ae }\end{array}$ & $\begin{array}{l}\text { Amla, } \\
\text { Kasaya, }\end{array}$ & $\begin{array}{l}\text { Guru, } \\
\text { Snighda }\end{array}$ & Sheeta & Madhura & $\begin{array}{l}\text { VPR } \\
\text { shamaka } \\
\text { (Keshya) }\end{array}$ & $\begin{array}{l}\text { Guduchyadi } \\
, 14,264\end{array}$ \\
\hline 6 & $\begin{array}{l}\text { Sindhuva- } \\
\text { ra } \\
\text { (Panchang } \\
\text { a) }\end{array}$ & $\begin{array}{l}\text { Vitex negun- } \\
\text { do Linn. }\end{array}$ & $\begin{array}{l}\text { Verbenace- } \\
\text { ae }\end{array}$ & $\begin{array}{l}\text { Tikta, } \\
\text { Kasaya, } \\
\text { Katu }\end{array}$ & Laghu & Ushna & Katu & $\begin{array}{l}\text { KV } \\
\text { shamaka } \\
\text { (Keshya) }\end{array}$ & $\begin{array}{l}\text { Guduchyadi } \\
\text {,113,329 }\end{array}$ \\
\hline 7 & $\begin{array}{l}\text { Gunja } \\
\text { (Seeds) }\end{array}$ & $\begin{array}{l}\text { Abrus } \\
\text { precatorius } \\
\text { Linn. }\end{array}$ & Fabaceae & $\begin{array}{l}\text { Tikta, } \\
\text { Kashaya }\end{array}$ & $\begin{array}{l}\text { Laghu, } \\
\text { Ruksha }\end{array}$ & Ushna & Katu & $\begin{array}{l}\text { VP } \\
\text { shamak } \\
\text { (Keshya, } \\
\text { In- } \\
\text { dralupta) }\end{array}$ & $\begin{array}{l}\text { Guduchyadi } \\
, 125,339\end{array}$ \\
\hline 8 & $\begin{array}{l}\text { Neeli } \\
\text { (Panchang } \\
\text { a) }\end{array}$ & $\begin{array}{l}\text { Indigofera } \\
\text { tinctoria } \\
\text { Linn. }\end{array}$ & Fabaceae & Tikta & $\begin{array}{l}\text { Laghu, } \\
\text { Ruksha }\end{array}$ & Ushna & Katu & $\begin{array}{l}\text { KV } \\
\text { shamaka } \\
\text { (Keshya) }\end{array}$ & $\begin{array}{l}\text { Guduchyadi } \\
\text {,207, } 392\end{array}$ \\
\hline 9 & $\begin{array}{l}\text { Bhringara- } \\
\text { ja } \\
\text { (Panchang } \\
\text { a) }\end{array}$ & $\begin{array}{l}\text { Eclipta alba } \\
\text { Hassk. }\end{array}$ & Compositae & Katu & $\begin{array}{l}\text { Tikshna, } \\
\text { Ruksha }\end{array}$ & Ushna & Katu & $\begin{array}{l}K V \\
\text { shamaka } \\
\text { (Keshya) }\end{array}$ & $\begin{array}{l}\text { Guduchyadi } \\
\text { 239, } 414\end{array}$ \\
\hline 10 & $\begin{array}{l}\text { Saireyaka } \\
\text { (Patra, } \\
\text { Moola) }\end{array}$ & $\begin{array}{l}\text { Barleria } \\
\text { prionitis } \\
\text { Linn. }\end{array}$ & $\begin{array}{l}\text { Acanthace- } \\
\text { ae }\end{array}$ & $\begin{array}{l}\text { Tikta, } \\
\text { Madhura, } \\
\text { kinchit } \\
\text { Amla }\end{array}$ & Atisnigdha & Ushna & Katu & $\begin{array}{l}\text { VRK } \\
\text { shamaka } \\
\text { (Kesha } \\
\text { ranjana) }\end{array}$ & $\begin{array}{l}\text { Puspa, } \\
49,489\end{array}$ \\
\hline 11 & $\begin{array}{l}\text { Japa pus- } \\
\text { pa } \\
(\text { Puspa) }\end{array}$ & $\begin{array}{l}\text { Hibiscus } \\
\text { rosasinensis } \\
\text { Linn. }\end{array}$ & Malvaceae & $\begin{array}{l}\text { Kasaya, } \\
\text { Tikta }\end{array}$ & $\begin{array}{l}\text { Laghu, } \\
\text { Ruksha }\end{array}$ & Sheeta & Katu & $\begin{array}{l}K V \\
\text { shamaka } \\
\text { (Keshya) }\end{array}$ & $\begin{array}{l}\text { Puspa, } \\
58,493\end{array}$ \\
\hline 12 & $\begin{array}{l}\text { Bijaka } \\
\text { (Sara) }\end{array}$ & $\begin{array}{l}\text { Pterocarpus } \\
\text { marsupium } \\
\text { Roxb. }\end{array}$ & Fabaceae & $\begin{array}{l}\text { Kasaya, } \\
\text { Tikta }\end{array}$ & $\begin{array}{l}\text { Laghu, } \\
\text { Ruksha }\end{array}$ & Sheeta & Katu & $\begin{array}{l}\text { KRP } \\
\text { shamak } \\
\text { (Keshya) }\end{array}$ & $\begin{array}{l}\text { Vatadi, } \\
28,512\end{array}$ \\
\hline 13 & Kashisham & & & $\begin{array}{l}\text { Amla, } \\
\text { Tikta, } \\
\text { Kasaya }\end{array}$ & 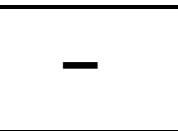 & Ushna & & $\begin{array}{l}\text { KV } \\
\text { shamaka } \\
\text { (Keshya) }\end{array}$ & $\begin{array}{l}\text { Dhatvadi, } \\
152,609\end{array}$ \\
\hline 14 & Tila (Seed) & $\begin{array}{l}\text { Sesamum } \\
\text { indicum } \\
\text { Linn. }\end{array}$ & Pedaliaceae & $\begin{array}{l}\text { Katu, } \\
\text { Tikta, } \\
\text { Madhura, } \\
\text { Kashya }\end{array}$ & $\begin{array}{l}\text { Guru, } \\
\text { Snigdha }\end{array}$ & Ushna & Katu & $\begin{array}{l}\text { KP } \\
\text { shamaka } \\
\text { (Keshya) }\end{array}$ & $\begin{array}{c}\text { Dhanya, } \\
63,638\end{array}$ \\
\hline 15 & $\begin{array}{l}\text { Kadali } \\
(\text { Kanda) }\end{array}$ & $\begin{array}{l}\text { Musa sapi- } \\
\text { entum Linn. }\end{array}$ & Musaceae & Madhura & & Sheeta & & $\overline{(\text { Keshya }}$ & $\begin{array}{l}\text { Shaka, } \\
105,685\end{array}$ \\
\hline 16 & $\begin{array}{l}\text { Avi dug- } \\
\text { dha }\end{array}$ & Sheep milk & & $\begin{array}{l}\text { Lavana, } \\
\text { Madhura }\end{array}$ & $\begin{array}{l}\text { Snigdha , } \\
\text { Guru }\end{array}$ & Ushna & & $\begin{array}{l}\text { PK kara } \\
\text { V } \\
\text { shamaka } \\
\text { (Keshya) }\end{array}$ & $\begin{array}{l}\text { Dugdha,19, } \\
745\end{array}$ \\
\hline
\end{tabular}


traditionally claimed hair growth promoting property. Topical application of formulation was done and hair growth initiation time and hair growth completion time was visually observed in experimentally induced alopecia animal models. Study showed that the prepared formulation of these drugs have hair growth promoting capability and have potential to cure alopecia as well. (10)

\section{Observations and Results:}

\section{Graph No 1: Keshya drugs according to Rasa}

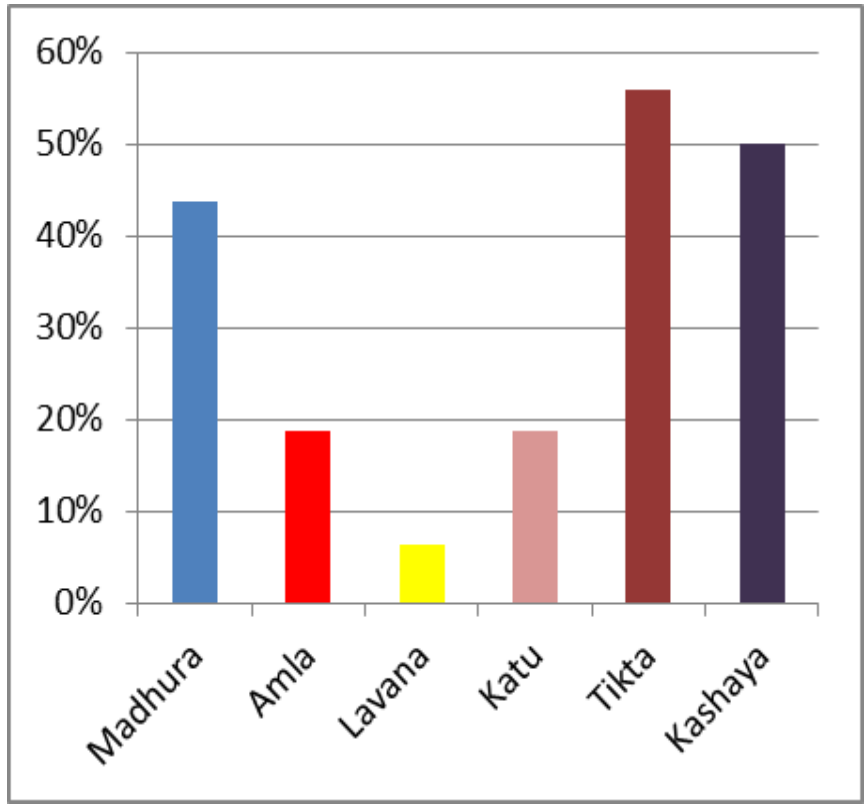

Graph No 2: Keshya drugs according to Guna

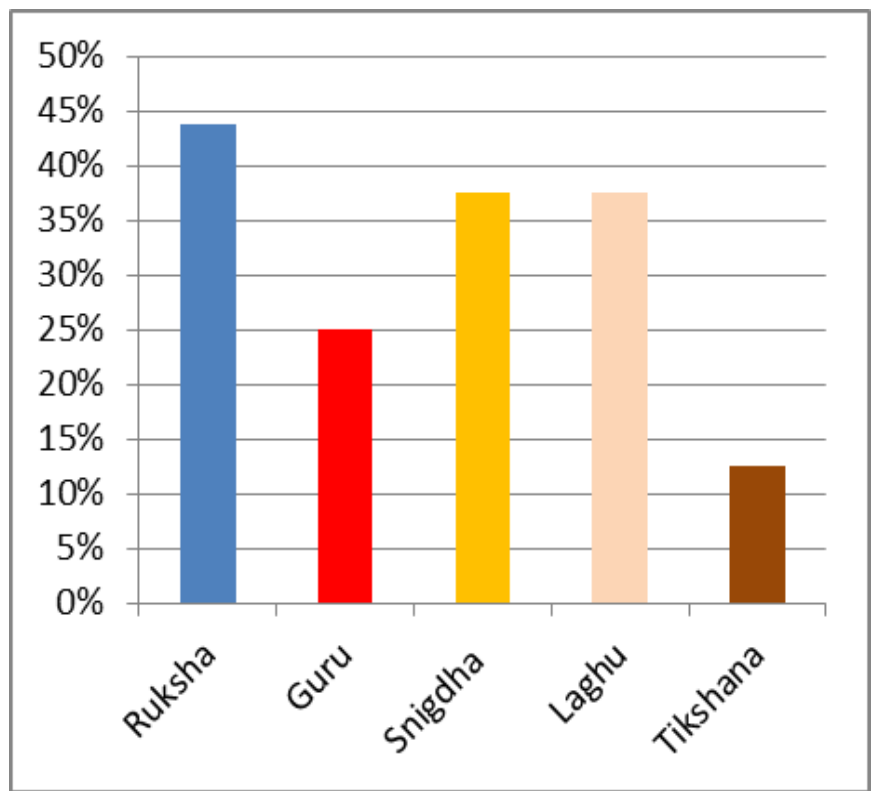

Graph no 1: Showing that the most of the drugs are having Tikta, Kashaya and Madhura predominant rasa. Similarly graph no 2 is showing that most of the drugs are having ruksha, snigdha and laghu guna predominant.
Graph no 3: Keshya drugs according to the Virya

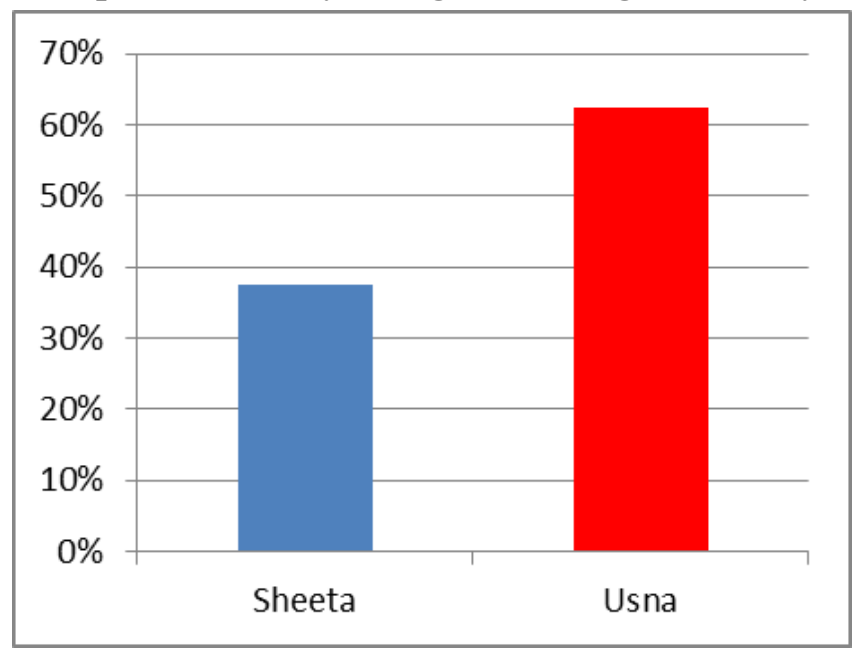

Graph No 4: Keshya drugs according to the Vipaka

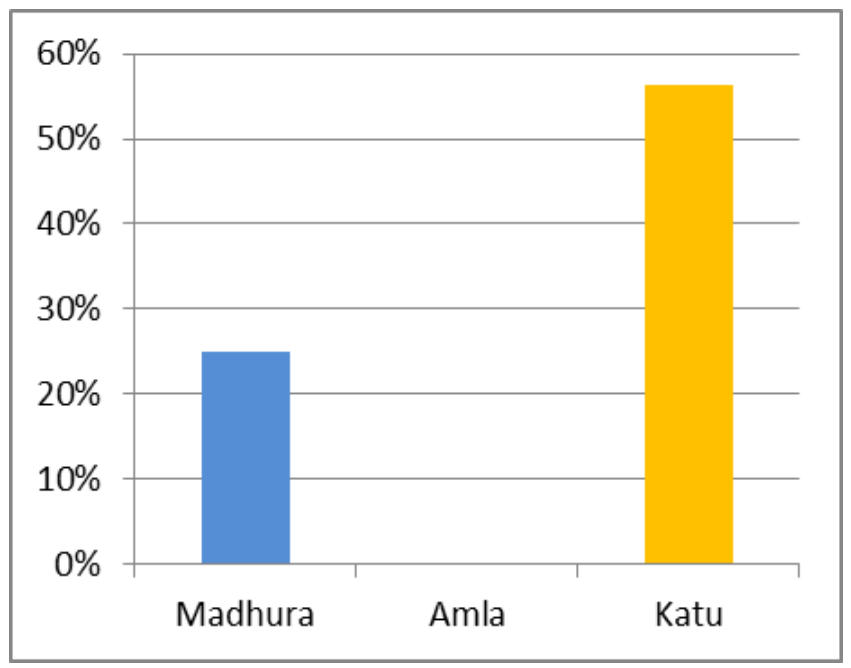

Graph no 3 is showing that most of the keshya drugs described in Bhava Prakasha Nighantu are having ushna virya and similarly graph no 4 indicating that most of the drugs are having katu vipaka.

\section{Graph No 5: Keshya drugs according to the Dosha} Karma

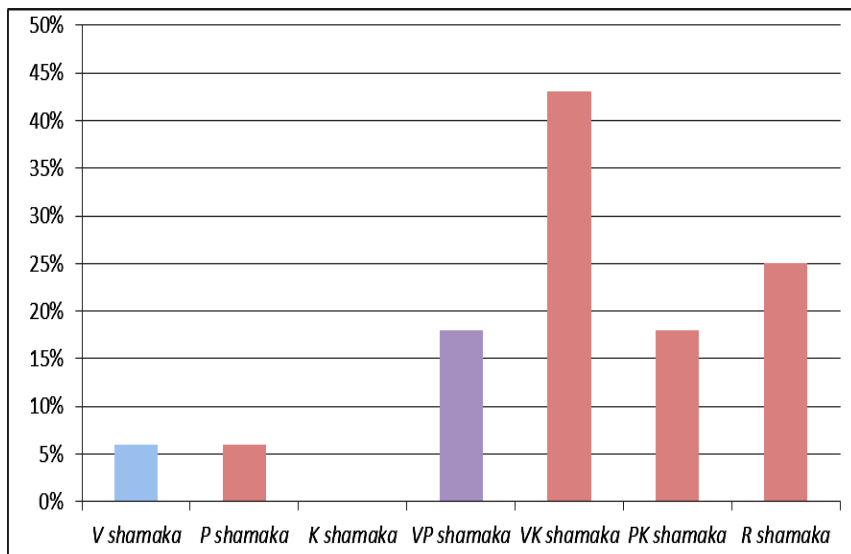

According to doshika karma graph no 5 is showing that most of the drugs are $V K$ shamaka and $P K$ shamaka. 


\section{Discussion}

Most of the diseases described in Ayurveda related to hair are Khalitya(Gradual falling of hairs), Palitya(Whitening of hairs), Indralupta(Sudden falling of hairs) etc. According to Sushruta, the samprapti of Khalitya is as follows- The vitiated vata takes the pitta to the romakupa which leads to hair fall, there after the vitiated rakta along with kapha blocks the romakupa which leads to permanent hair loss i.e. Khalitya. In case of Palitya, the vitiated pitta enters into the romakupa and leads to discolouration of hair.

From the above study it is observed that most of the keshya drugs described in Bhava Prakasha Nighantu are having Tikta, Kashaya and Madhur rasa, Ruksha guna, Usna Virya, Katu vipaka, and VK shamaka property. As above said that vitiated Vata and Pitta are responsible for hair fall and vitiated Rakta and Kapha are responsible for permanent hair fall. Similarly vitiated Pitta is responsible for discoloration of hair. As Tikta, Kashaya and Madhur rasas are Pitta shamaka, Ruksha guna and Usna Virya are vata shamaka and Katu vipaka is Kapha shamaka. Hence these drugs are helpful in checking hair fall and discoloration of hair. So these drugs are definitely having keshya property.

In Khalitya, vata and pitta doshas are vitiated. The drugs which are having vata- pitta shamaka property are helpful in Khalitya such as Gunja. The drugs having pitta shamaka properity are helpful in Palitya such as Bhallataka vrint. Similarly the drugs having rakta and kapha shamaka properity are helpful in permanent hair loss such as Saireyaka.

\section{Conclusion}

Keshya drugs are the drugs which are beneficial to hair by helping in the origin of hair, promoting hair growth, make hair dense and thick or give dark black colour to hairs. There are so many diseases described in Ayurveda which are related to hairs such as Khalitya, Palitya, Indralupta etc. There are so many drugs described in Ayurvedic texts which are benificeal in these diseases such as Yastimadhuka tail, Nilikadya tail, Bhringaraja tail, Triphala ghrita, Abhraka bhasma, Sadabindu tail, Triphaladi tail, Bhringamalakadi tail, Nilibhringadi tail, Narasimha churna etc. but in Bhava Prakasha Nighantu total 16 drugs are found having
Keshya property, out of which 14 drugs are of plant origin, one is rasa ausadi and one is of animal origin. Out of 14 plant origin drugs we are able to find only 3 plants (Yastimadhu, Bhringaraja and Japa puspa) on which research work have been done in reference to Keshya karma. It indicate that there is a need of research work on remaining plants.

\section{References}

1. Gerard J. Tortora, Bryan Derrickson. Principals Of Anatomy And Physiology. $11^{\text {th }}$ edtion. Danvers; John Wiley \& Sons; 2006, 152p.

2. Pasricha JS, Ramji gupta. Illustrated Textbook of Dermatology. $2^{\text {nd }}$ ed. New Delhi; Jaypee Brothers; 2001,118p.

3. https://www.scribd.com/collections/3567269/ Halayudha-Kosha (Jaishankar Joshi. HalayudhaKosha. 2nd ed. 245p)

4. Tritiya sansakarana Sam. Shree Taranathbhattacharyena Shabdastoya Mahanidhi. Varanasi; Chaukhambha granth sankhya 101; 2023 Visvi. 135p

5. Monier, Monier Williams, Sir. Sir Monier Monier Williams Sanskrit-English dictionary; Marwah Publication; 1986, 310p.

6. Acharya Priyavrat Sharma. Dravyagun Vigyan vol 1. Revised golden jubilee-Edition; Varanasi; Chaukhambha Bharati Academy; 2008, 312p.

7. http://easyayurveda.com/2014/08/06/ayurvedic-haircare-principles-herbs-oils-medicines/

8. Sukirti Upadhyay, Ashoke K Ghosh and Vijender Singh. Hair growth promotant activity of petroleum ether root extract of Glycyrrhiza glabra L.(fabaceae) in female rats. Tropical Journal of Pharmaceutical Research. 2012; 11(5); 753-758

9. Kakali Datta, Anu T. Singh, Ashok Mukherjee, Beena Bhat, B. Ramesh, Anand C. Burman. Eclipta alba extract with potential for hair growth promoting activity.Journal of Ethnopharmacology.2009; 124 (3) ; 450-456

10.Sabarwal Neetu, Varghese Dhanila, Barik Rakesh, Khandelwal Anjali, Jain Ashish, Jain Sanjay. Development and evaluation of polyherbal formulations for hair growth activity. Pharmacognosy Journal. 2009; 1(2); 165-170 